\title{
Geen schakeljaar in de basisopleiding geneeskunde ${ }^{1}$
}

\author{
J. Bekker • J. Bekker
}

De stap van coassistent naar arts is groot. Opeens is daar de bevoegdheid om recepten voor te schrijven, zelfstandig visite te lopen en moeten er zelfstandig nachtdiensten gedaan worden. Een geleidelijker overgang is welkom en een schakeljaar kan volgens velen uitkomst bieden. ${ }^{1-3}$ Het 6e en laatste jaar van de basisopleiding noemt men het schakeljaar. De medische faculteiten van de universiteiten van Utrecht en Leiden zijn hier in 2004 voor het eerste bij wijze van proef mee begonnen. Het schakeljaar beoogt een verdere ontwikkeling en een verdieping in een eigen gekozen richting. Vaste onderdelen zijn een algemene semi-artsstage (ASAS) en een wetenschappelijke stage. Beide onderdelen hebben een duur van drie maanden. De semi-arts heeft de keuze de wetenschappelijke stage of de ASAS te verlengen met drie maanden. In Utrecht wordt de rest van het jaar opgevuld met onderwijs en stages.

Het keuzecoassistentschap en het oudste coassistentschap zijn normaal gesproken de laatste twee coassistentschappen van het 6e jaar en hebben samen een duur van zes maanden. Waarin verschillen ze nu van een ASAS? Er blijkt nauwelijks verschil te zijn: tijdens de ASAS functioneert de student als beginnende arts, maar dan zonder de formele bevoegdheid van de BIG-geregistreerde arts. ${ }^{1}$ De naam 'ASAS' is anders dan 'keuzecoassistentschap' of 'oudste coassistentschap', maar het lijkt verder om hetzelfde te gaan. ${ }^{2}$ De stap van semi-arts naar echte arts blijft even groot. $^{2-3} \mathrm{Er}$ is geen extra voordeel van het semi-artsschap ten opzichte van het keuzecoassistentschap of het oudste coassistentschap.

J. Bekker $(\bowtie)$

is arts-onderzoeker Universitair Medisch Centrum Groningen.

Correspondentieadres:
Een argument voor een schakeljaar is dat de semi-arts sneller medisch specialist kan worden, als men tenminste direct een opleidingsplek krijgt (www. medischevervolgopleidingen. nl). De arts niet in opleiding tot specialist (anios) zou zo zelfs overbodig worden. ${ }^{1}$ Dit lijkt echter geen reële voorstelling van zaken. Het probleem ligt namelijk niet bij de basisopleiding, maar bij de vervolgopleidingen. De opleiding kindergeneeskunde zit al enkele jaren vrijwel op slot. De opleiding chirurgie heeft al jaren een stabiel aantal plaatsen van 56 per jaar (www.heelkunde.nl). Het maakt dus niet uit of men semi-arts geweest is, want de vervolgopleiding komt men toch niet direct in. Een aniosschap duurt nu gemiddeld drie jaar voordat men een vervolgopleiding kan starten. ${ }^{1}$ Het ophogen van het aantal opleidingsplekken kan echter zomaar niet: niemand heeft wat aan werkloze kinderartsen, internisten of chirurgen.

Kortom: er is eigenlijk niet zoveel veranderd met de komst van het schakeljaar. De tijdwinst die te behalen is met een schakeljaar bij de basisopleiding lijkt gering. Het aniosschap blijft voorlopig nog belangrijk, omdat er op korte termijn waarschijnlijk geen snellere doorstroming komt naar vervolgopleidingen.

Belangenconflict: geen gemeld.

Financiële ondersteuning: geen gemeld.

\section{Summary}

The step from houseman to residency is a large one. The medical curricula at the universities of Leiden and Utrecht have started a project called the "schakeljaar" (connecting year). Such a connecting year is intended to make the transition smoother and may have the added advantage that one can start the postgraduate training more quickly. However, there are some critical remarks that can be made here. First of all, there does not seem to be such a major difference between the doctor that one becomes during the

\footnotetext{
${ }^{1}$ Dit artikel verschijnt ook in het Nederlands Tijdschrift voor Geneeskunde.
} 
connecting year and the currently common optional houseman or eldest houseman. Secondly, it is questionable whether one can really start the postgraduate training more quickly. The capacity of the postgraduate training programmes is limited. Thirdly, relatively little time can be saved in the basic medical curriculum. (Bekker J. No 'connecting year' in the medical curriculum. Dutch Journal of Medical Education 2007;26(4):197-198.)

\section{Literatuur}

Borleffs JCC, Pieters HM, Schaik JPJ van, Verbout AJ, Wall E van der. Een hobbelig traject, problemen met implementatie schakeljaar. Med Contact 2006;61:1575-7.
Schipholt IL. Net echt, werken als arts tijdens je studie. Twee semiartsen over hun stage in het schakeljaar: "Wij mogen veel meer doen dan tijdens de co-schappen". Arts in Spe 2005;2:6-7.

Rijken J, Jong G de. Vóór landelijke invoering van het schakeljaar. Arts in Spe 2005;4:13. 